\title{
Molecular detection of Ehrlichia canis and Anaplasma platys in dogs in Southern Brazil
}

\author{
Detecção molecular de Ehrlichia canis e Anaplasma platys em cães do sul do Brasil \\ Camila Serina Lasta ${ }^{1}$; Andrea Pires dos Santos ${ }^{2 *}$; Joanne Belle Messick²; Simone Tostes Oliveira ${ }^{3}$; \\ Alexander Welker Biondo ${ }^{3,4}$; Rafael Felipe da Costa Vieira ${ }^{5}$; Magnus Larruscaim Dalmolin'; \\ Félix Hilario Diaz González ${ }^{1}$
}

\author{
${ }^{1}$ Departamento de Patologia Clínica Veterinária, Universidade Federal do Rio Grande do Sul - UFRGS, Porto Alegre, RS, Brasil \\ ${ }^{2}$ Department of Comparative Pathobiology, Purdue University - West Lafayette, IN, USA \\ ${ }^{3}$ Departamento de Medicina Veterinária, Universidade Federal do Paraná - UFPR, Curitiba, PR, Brasil \\ ${ }^{4}$ Department of Veterinary Pathobiology, University of Illinois - Urbana, IL, USA \\ ${ }^{5}$ Departamento de Ciências Veterinárias, Universidade Federal da Paraíba - UFPB, Areia, PB, Brasil \\ ${ }^{6}$ Centro de Biotecnologia, Universidade Federal do Rio Grande do Sul - UFRGS, Porto Alegre, RS, Brasil
}

Received February 262013

Accepted July 102013

\begin{abstract}
The aims of this study were to determine the occurrence of Anaplasma platys and Ehrlichia canis infection in dogs in Porto Alegre, Southern Brazil; and to investigate their association with hematological abnormalities. Serum samples from 196 dogs were first tested using dot-ELISA for antibodies against Anaplasma spp. and Ehrlichia canis. Peripheral blood samples from 199 dogs were subjected to 16S rRNA nested PCR (nPCR) for A. platys and E. canis, followed by DNA sequencing to ensure pathogen identity. A total of 19/196 samples (9.69\%) were positive for Anaplasma spp. using ELISA and 28/199 (14.07\%) samples were positive for $A$. platys by nested PCR. All the dog samples were negative for $E$. canis, both in anti-E. canis antibody tests and in nested PCR. There were no significant differences in hematological parameters between $A$. platys-PCR positive and negative dogs and Anaplasma spp. serologically positive dogs, except for basophil counts, which were higher in nPCR-positive dogs. This is the first report showing $A$. platys presence in dogs in Southern Brazil. In conclusion, hematological parameters may not be sufficient to diagnose $A$. platys infection in dogs in Southern Brazil, probably due either to low pathogenicity or to chronic infection. On the other hand, E. canis may either have very low occurrence or be absent in dogs in Porto Alegre.
\end{abstract}

Keywords: Anaplasmataceae, dogs, Southern Brazil, 16S rRNA gene.

\section{Resumo}

O objetivo deste estudo foi determinar a ocorrência de Anaplasma platys e Ehrlichia canis em cáes de Porto Alegre, sul do Brasil, sua detecção molecular e associação com anormalidades hematológicas. Amostras séricas de 196 cães foram inicialmente triadas por dot-ELISA para a presença de anticorpos contra Anaplasma spp. e Ehrlichia canis. Amostras de sangue periférico de 199 cães foram submetidas à nested PCR (16S rRNA) para A. platys e E. canis, seguido de sequenciamento do DNA para confirmar a identidade do agente. Do total, 19/196 (9,69\%) amostras foram positivas para Anaplasma spp. por dot-ELISA e 28/199 (14,07\%) por nPCR. Todas as amostras dos cães foram negativas para $E$. canis no teste sorológico anti-E. canis e também na nPCR. Não houve diferença significativa nos parâmetros hematológicos, exceto a contagem de basófilos, que apresentou valores mais altos em cáes positivos na nPCR para $A$. platys. Este é o primeiro relato da presença de $A$. platys no Rio Grande do Sul, e a primeira detecção molecular do agente no sul do Brasil. Em conclusão, parâmetros hematológicos não são suficientes para diagnosticar a infecção por $A$. platys em cães, provavelmente devido sua baixa patogenicidade ou infecção crônica. Por outro lado, E. canis parece ter ocorrência baixa ou mesmo nula em cães de Porto Alegre.

Palavras-chave: Anaplasmataceae, cães, sul do Brasil, gene 16S rRNA.

${ }^{*}$ Corresponding author: Andrea Pires dos Santos

Purdue University, 725 Harrison Street, West Lafayette, IN, 47907, USA

e-mail: santos1@purdue.edu 


\section{Introduction}

Anaplasma platys and Ehrlichia canis are tick-borne bacteria that cause mild to severe disease in dogs (BEALL et al., 2008; GAUNT et al., 2010). Both organisms are transmitted by ticks, mainly by Rhipicephalus sanguineus. Anaplasma platys - formerly known as Ehrlichia platys (DUMLER et al., 2001) - and E. canis, from the Anaplasmataceae family, cause canine infectious cyclic thrombocytopenia (CICT) and canine monocytic ehrlichiosis (CME), respectively (HARVEY, 2006; DANTAS-TORRES, 2008).

Anaplasma platys develops inside canine platelets, with no clearly established pathogenic role in dogs (AGUIRRE et al., 2006; HARVEY, 2006). Reports on experimental and natural infections have mostly indicated that $A$. platys causes few or no clinical signs in dogs in the United States (HARVEY, 2006; GAUNT et al., 2010). However, $A$. platys strains are reportedly more virulent in France, Spain, Turkey and Tunisia (BEAUFILS et al., 2002; AGUIRRE et al., 2006; ULUTAS et al., 2007, M'GHIRBI et al., 2009), with clinical signs that are probably influenced by stress, immune status, breed predisposition (AGUIRRE et al., 2006) or strain variability. In contrast, $E$. canis infects monocytes and has been associated with serious and sometimes fatal disease in dogs (NEER; HARRUS, 2006). It has also been suggested to be a zoonotic agent in Venezuela (PEREZ et al., 1996, 2006).

No serological surveys on $A$. platys have been performed to date in Brazil, whereas the seroprevalence of E. canis in dogs in Brazil may range from 0.7 to $92.3 \%$, depending on the population, geographical area and diagnostic test used (OLIVEIRA et al., 2000; LABARTHE et al., 2003; VIEIRA et al., 2011). Moreover, molecular detection of $A$. platys and $E$. canis in dogs has been conducted in Brazil and has shown widely variable prevalence, from 7.8 to $88 \%$ and from 8.1 to 55\%, respectively (DAGNONE et al., 2003, 2009; COSTA Jr., 2007b; RAMOS et al., 2009; SANTOS et al. 2009a).

Although $R$. sanguineus is a commonly found tick species in Southern Brazil (RIBEIRO et al., 1997), it has not yet been fully established whether $A$. platys and $E$. canis cause infection in dogs in the state of Rio Grande do Sul. Accordingly, the aims of the present study were to determine the serological and molecular prevalence of $A$. platys and $E$. canis and to correlate infection with hematological abnormalities in two populations of naturally infected dogs in Porto Alegre, the capital of Rio Grande do Sul, Southern Brazil.

\section{Materials and Methods}

\section{Study population and samples}

This study was carried out in the city of Porto Alegre ( $30^{\circ} 01^{\prime} 59^{\prime \prime} \mathrm{S}$ and $\left.51^{\circ} 13^{\prime} 48^{\prime \prime} \mathrm{W}\right)$, the capital of the state of Rio Grande do Sul, Southern Brazil, with an estimated population of $1,400,000$ inhabitants. Blood samples were collected between May 2007 and February 2009, from 53 stray dogs at the city's Zoonosis Control Center and 146 semi-owned dogs (dogs that were living outdoors, with full access to the streets, i.e. free roaming) on a low-income island (Arquipelago district) within the city limits, thus totaling 199 dogs. Only one sample was taken from each dog.
The Arquipelago district is the biggest in Porto Alegre and is formed by 15 islands. Its population is approximately 5,000 inhabitants and most of them rely on garbage recycling. The Zoonosis Control Center did not have precise information about where each dog was initially caught, but it functions throughout the city. The data recorded on each animal included information on breed, age and location. In the Arquipelago district, the dogs were selected by convenience, at times when clients volunteered their dogs during attendance campaigns, without specific inclusion criteria. Only the animals that were receiving antibiotic therapy were excluded from the study. This work was approved by the Ethics Committee for Animal Experimentation and Animal Welfare of Universidade Federal do Rio Grande do Sul (UFRGS) (number 13.313).

\section{Blood collection and hematological analysis}

Blood samples were collected and aliquoted into EDTA tubes for hematological analyses and PCR, and into serum tubes for serological tests. Samples from three dogs had insufficient volume for serum tests. Blood cell counts were determined as previously described (RIZZI et al., 2010). Blood smears were examined microscopically for the presence of morulae, and the peripheral blood smear WBC differential was ascertained by counting 100 leukocytes. This was done by a person who was blinded to the serological and nPCR results.

\section{Serological test: dot-ELISA-based assay}

Samples were tested for antibody reactivity against $E$. canis and Anaplasma spp. using a commercial rapid in-clinic ELISA assay (SNAP 4Dx ${ }^{\oplus}$ test kit, IDEXX Laboratories, Inc., Westbrook, Maine, USA), according to the manufacturer's instructions.

\section{DNA extraction, nested PCR and DNA sequencing}

DNA was isolated from $200 \mu \mathrm{L}$ of EDTA blood using the QIAamp DNA Blood Mini kit (Qiagen, Valencia, California, USA), following the manufacturer's instructions. Negative control purifications using ultra-pure water were performed to monitor cross-contamination for each batch of 10 samples. To verify the existence of amplifiable DNA in the samples, a PCR assay for the housekeeping gene glyceraldehyde-3-phosphate dehydrogenase (GAPDH) was performed as previously described (SANTOS et al., 2009b).

Samples were initially screened using the universal primer fD1 and the genus-specific primer EHR16SR (INOKUMA et al., 2001). These primers amplify $760 \mathrm{bp}$ of the partial sequence of the 16S rRNA gene of Ehrlichia and Anaplasma species. Briefly, $5 \mu \mathrm{L}$ of DNA was used as a template for the primary amplification, in a total reaction mixture of $25 \mu \mathrm{L}$ containing $1.5 \mathrm{mM}$ of $\mathrm{MgCl}_{2}$, $0.2 \mathrm{mM}$ of each deoxynucleoside triphosphate (dNTP), $0.25 \mathrm{U}$ of Taq polymerase (Go Taq Fexi Promega, Madison, WI, USA) and $0.1 \mathrm{mM}$ of each primer. After initial denaturation at $94^{\circ} \mathrm{C}$ for $1 \mathrm{~min}$, the amplification consisted of 35 cycles of $1 \mathrm{~min}$ each at temperatures of $94^{\circ} \mathrm{C}, 55^{\circ} \mathrm{C}$ and $72{ }^{\circ} \mathrm{C}$ for denaturation, annealing and extension, respectively. 
The second amplification (nested PCR) was carried out using the primers CANIS and GA1UR for E. canis (504 bp), and PLATYS $\mathrm{F}$ and PLATYS R for $A$. platys (408 bp) with a few modifications (INOKUMA et al., 2001), which included: 1) PCR products were diluted 1:5 with nuclease-free water; and 2) $1 \mu \mathrm{L}$ of the solution was used as the template DNA for the second reaction. The conditions for the PCR amplification were the same as for the first round of PCR, except for the annealing temperature for E. canis $\left(57.6^{\circ} \mathrm{C}\right)$ and the number of cycles (39). The positive controls were 10 -fold dilutions of a plasmid containing starting concentrations of $5.47 \times 10^{9}$ and $6.18 \times 10^{10}$ copies $/ \mu \mathrm{L}$ of the $16 \mathrm{~S}$ rRNA gene of $E$. canis and $A$. platys, respectively, until reaching less than 1 copy/ $\mu \mathrm{L}$. In each PCR run, the negative control consisted of all reagents (excluding sample) and ultra-pure water. The negative control from the first PCR run was also used as the negative control in the second run. Positive controls, including the control with the lowest copy number (determined as the detection limit for each assay) were included in every run.

The amplified PCR products were subjected to gel electrophoresis in $1.5 \%$ agarose gels for one hour at $100 \mathrm{~V}$, followed by ethidium bromide staining $(1 \mu \mathrm{g} / \mathrm{mL})$, and were viewed under a $312 \mathrm{~nm} \mathrm{UV}$ light transilluminator. The gels were subsequently photographed using Epi Chem II Darkroom ${ }^{\circledast}$ (UVP, Inc., Upland, California, USA). In order to minimize potential risks of contamination, DNA extractions, PCR preparation, PCR amplification, and agarose gel electrophoresis were performed in separate rooms.

All the nPCR products were purified using the QIAprep Spin Miniprep kit (QIAGEN), and the amplicons were directly sequenced with both forward and reverse primers (Purdue Genomics Core Facility, Purdue University, West Lafayette, Indiana, USA). Primers were deleted from DNA sequences obtained from the Anaplasma platys 16S rRNA gene and were compared with those of the GenBank ${ }^{\oplus}$ database using the BLAST $^{\circledast}$ nucleotide (ALTSCHUL et al., 1990) in order to search for identicalness.

\section{Positive controls}

Positive controls were obtained from dogs naturally infected by $E$. canis and $A$. platys in the city of Londrina, state of Paraná, Southern Brazil. To construct reliable positive controls, nPCR for $E$. canis and $A$. platys detection was performed as described above. Amplicons (504 bp fragment of the 16S rRNA gene for $E$. canis and 408 bp fragment for $A$. platys) were purified from gel (Zymoclean DNA Gel Recovery, Zymo Research, Orange, California, USA), and were cloned into the pGEM-T Easy Vector (Promega, Madison, Wisconsin, USA) followed by transformation in JM 109 Competent Cells (Promega, Madison, Wisconsin, USA). Plasmids with inserts were isolated, grown and purified using a commercial kit (Miniprep, QIAGEN, Valencia, California, USA).

The DNA concentration of positive controls was quantified by means of scanning UV spectrophotometry (NanoDrop ${ }^{\oplus} \mathrm{ND}$ 1000 UV/Vis Spectrophotometer, Thermo Fisher Scientific Inc., Wilmington, Delaware, USA) to determine the number of copies/ $\mu \mathrm{L}$. The detection limit for the nPCR was determined by using serial 10-fold dilutions of the positive plasmid controls, spiked in Herring Sperm DNA (KPL, Gaithersburg, Maryland, USA) as the DNA template.

\section{Statistical analysis}

Statistical univariate analysis on associations between seropositivity and PCR results and hematological parameters was conducted using the chi-square test. Fisher's exact test was used to evaluate associations between seropositivity and nPCR positivity status when the expected frequency was less than five, using the Stata 11.1 software (Stata Corp, College Station, Texas, USA). Statistical significance was defined as $\mathrm{p}<0.05$.

\section{Results}

The nPCR assays were able to amplify the control template diluted to as few as $10^{1}$ and $10^{3}$ gene copies per microliters for $E$. canis and $A$. platys, respectively, and all the samples were positive for GAPDH, thereby confirming the presence of amplifiable DNA in the samples.

All the samples were negative for the presence of antibodies for $E$. canis and E. canis $16 S$ rRNA DNA. Among the dog serum samples, $19 / 196$ (9.69\%) showed antibodies that were reactive to Anaplasma spp. using the SNAP 4Dx ${ }^{\oplus}$ test. A platys DNA (16S rRNA gene) was amplified by nPCR in 28/199 dogs (14.07\%). There was no positive association between the PCR and ELISA results $(\mathrm{p}>0.05)$.

Among the $28 \mathrm{~A}$. platys nPCR-positive dogs, 7 ( $\mathrm{n}=53$ ) were from the dogs from the city's Zoonosis Control Center (urban area) and 21 ( $n=146)$ from the Arquipelago district (suburban area). No statistical difference between PCR-positivity and location of the dogs was observed ( $p$-value $=0.448)$. Nineteen $(67.8 \%)$ of the $\mathrm{nPCR}$ positive dogs were anemic $\left(\mathrm{RBC}<5.5 \times 10^{6} / \mu \mathrm{L}\right)$ and $16(61.5 \%)$ were thrombocytopenic (platelets $<200 \times 10^{3} / \mu \mathrm{L}$ ) (Table 1). Two positive samples had fibrin-clot formation and the data from these samples were not included in the analyses. There was no association between a positive serological test or PCR and other CBC abnormalities except for the basophile count, which was higher the reference value for the leukocyte differential in PCR-positive dogs ( $\mathrm{p}=0.015)$.

The $A$. platys $16 \mathrm{~S}$ rRNA gene partial sequences obtained in this study were $100 \%$ identical to each other. A partial $16 \mathrm{~S}$ rRNA gene sequence of $408 \mathrm{bp}$, representative of all samples, was deposited in GenBank ${ }^{\circledR}$ database as the Porto Alegre isolate, under the accession number JF418996. Sequence comparisons on the $408 \mathrm{bp}$ fragment from Porto Alegre revealed that the amplicon sequences were identical (100\%) to A. platys samples from other Brazilian areas such as Campo Grande/MS/Center-West Brazil (JX118826) and Ribeirão Preto/SP/Southeast Brazil (EF052622), and from other countries: Philippines (Q8947792), Cape Verde (GQ395385), Croatia (JQ396431), Italy (EU439943), Malaysia (JF683610), Portugal (EU004823), Spain (AY530806), Japan (AF288136), Venezuela (HE856819) and Thailand (EF13945). The lowest identity (99.75\%) was with an $A$. platys sample identified in dogs in Venezuela (AF399917). A lower sequence identity of $98 \%$ was found in relation to a German sample of A. phagocytophilum (HM480383). 
Table 1. Anemia and thrombocytopenia associated with positive PCR for Anaplasma platys or serology for Anaplasma spp. from dogs.

\begin{tabular}{lccccc}
\hline $\begin{array}{c}\text { Clinical } \\
\text { manisfestation }\end{array}$ & $\begin{array}{c}\text { nPCR } \\
\text { positive }\end{array}$ & $\begin{array}{c}\text { nPCR } \\
\text { negative }\end{array}$ & $\mathbf{p}$ & $\begin{array}{c}\text { Serology } \\
\text { positive }\end{array}$ & $\begin{array}{c}\text { Serology } \\
\text { negative }\end{array}$ \\
\hline Anemia & $\mathrm{n}=28$ & $\mathrm{n}=171$ & & $\mathrm{n}=19$ & $\mathrm{n}=177$ \\
Yes & $67.8 \%(19)$ & $33.9 \%(58)$ & 0.85 & $36.8 \%(7)$ & $33.8 \%(60)$ \\
No & $32.1 \%(09)$ & $66.0 \%(113)$ & & $63.1 \%(12)$ & $66.1 \%(117)$ \\
Thrombocytopenia & $\mathrm{n}=26^{*}$ & $\mathrm{n}=169^{*}$ & & $\mathrm{n}=17^{*}$ & $\mathrm{n}=175^{*}$ \\
Yes & $61.5 \%(16)$ & $40.8 \%(69)$ & 0.45 & $58.2 \%(10)$ & $44.5 \%(78)$ \\
No & $38.4 \%(10)$ & $59.1 \%(100)$ & & $41.1 \%(7)$ & $55.4 \%(97)$ \\
\hline
\end{tabular}

*Two positive samples had fibrin-clot formation.

\section{Discussion}

All the samples tested negative for E. canis by PCR and the SNAP $4 \mathrm{Dx}^{\circ}$ test, thus suggesting that there was lower occurrence of E. canis in Porto Alegre than in other Brazilian regions. A previous study in Southern Brazil using serological tests showed low occurrence of E. canis in asymptomatic dogs, of $4.8 \%$ (SAITO et al., 2008). However, higher prevalence was found in other Brazilian regions, ranging from $24.8 \%$ to $44.7 \%$, using similar populations of dogs (AGUIAR et al., 2007; COSTA Jr et al., 2007a, SILVA et al., 2010; SOUZA et al., 2010). Although the tick vector $R$. sanguineus is abundant throughout all urban areas of Brazil (SAITO et al., 2008), including in the state of Rio Grande do Sul (RIBEIRO et al., 1997), it is important to consider that different populations of this tick species are found in Brazil (MORAES-FILHO et al., 2011). Thus, the negative results for $E$. canis found in the present study may have been due to differences in the vector competence of the $R$. sanguineus (SZABÓ et al., 2005). Although peripheral blood samples were used in this study, it may be postulated that false-negative results from nPCR for E. canis detection occurred because the agent could be sequestered in the spleen and bone marrow during the subclinical or chronic phase of the disease (MYLONAKIS et al., 2003). However, we did not find any seropositive (exposed) dog, which leads us to conclude that occurrence of E. canis in dogs in this work is very low or absent.

Six dogs showed positive results in both tests (Table 2). Thirteen dogs $(13 / 19,52.6 \%)$ that were serologically positive for Anaplasma sp. were negative according to nPCR, which suggests that there was a likelihood of previous exposure to the agent. Also, the cyclic parasitemia in dogs infected with $A$. platys may explain this discrepancy between serological and molecular results, as previously observed (FERREIRA et al., 2007, 2008b). Although A. phagocytophilum antigens are used in the commercial SNAP $4 \mathrm{Dx}^{\circ}$ test kit, $A$. platys antibodies cross-react with the $A$. phagocytophilum spot in this test (CHANDRASHEKAR, et al., 2010). The kit uses a synthetic peptide based on $\mathrm{p} 44$ A. phagocytophilum immunodominant protein and detects IgM and IgG antibodies. Because $A$. phagocytophilum and $A$. platys are closely related and share epitopes, the kit can be used for $A$. platys diagnosis (FERREIRA et al., 2008a.) On the other hand, many dogs (19/25, 76\%) that were positive by Anaplasma sp. nPCR were negative by serological tests for this agent (Table 2), which suggest that negative serological findings do not imply absence of organism infection (FERREIRA et al., 2008a). Positive Anaplasma sp. nPCR
Table 2. Anaplasma spp. serology and Anaplasma platys nPCR results in dogs.

\begin{tabular}{lccc}
\hline & \multicolumn{2}{c}{$\begin{array}{c}\text { Anaplasma spp. } \\
\text { Dot-ELISA }\end{array}$} & Total \\
\cline { 2 - 3 } & Negative & Positive & \\
\hline Anaplasma platys nPCR & & & \\
Negative & 158 & 13 & 171 \\
Positive & 19 & 6 & $25^{*}$ \\
Total & 177 & 19 & 196 \\
\hline
\end{tabular}

*Samples from three dogs had insufficient volume for serum tests.

results with negative serological results might also indicate an early stage of infection. Anaplasma sp. nPCR was able to detect $10^{3}$ gene copies per reaction, but it is also possible that dogs have lower numbers of copies of $A$. platys DNA, thus resulting in false negative results.

The possibility that dogs in our study were infected or co-infected with $A$. phagocytophilum cannot be ruled out, since dogs may be asymptomatic carriers for both agents. In a survey of zoonotic vector-borne diseases conducted previously in Botucatu, state of São Paulo, 198 sick dogs with clinical signs of tick-borne disease showed no evidence of $A$. phagocytophilum exposure or infection (DINIZ et al., 2007). In fact, $A$. phagocytophilum was recently detected in dogs by real-time PCR, in a survey conducted in the state of Rio de Janeiro (SANTOS et al., 2011), and in wild birds in the states of São Paulo and Goiás (MACHADO et al., 2012). Moreover, new genotypes of Anaplasmataceae agents have been reported in wild animals in Brazil (ANDRÉ et al., 2010, 2012; SACCHI et al., 2012).

Although dogs in Porto Alegre were infected by $A$. platys in the same way as described in other Brazilian regions (FERREIRA et al., 2007, 2008b; COSTA Jr, 2007b; DAGNONE et al., 2009; RAMOS et al., 2009), only two isolates have been molecularly characterized to date in Brazil (CARDOZO et al., 2007). Sequence comparisons on the partial $16 \mathrm{~S}$ rRNA gene in the samples from dogs in Porto Alegre revealed that the sequences were identical (100\%) to those from other locations in Brazil (Campo Grande/MS/ CenterWest Brazil and Ribeirão Preto/SP/Southeast Brazil), as well as to those from other strains around the world (INOKUMA et al., 2000, 2001; AGUIRRE et al., 2006; PINYOOWONG et al., 2008; GÖTSCH et al., 2009; DYACHENKO et al., 2012).

Anemia and thrombocytopenia are common findings associated with $A$. platys infection, even in asymptomatic dogs (HARVEY, 2006; FERREIRA et al., 2008b). However, occurrences of anemia 
or thrombocytopenia did not show any association with positive PCR or serological findings in the present study (Table 1). It can be explained by bad nutritional status, since most of these dogs are fed food scraps, garbage or low quality diet. These co-finding factors might have interfered with the statistical analyses.

The WBC varied among the dogs in the present study, which is consistent with previous reports of $A$. platys infection showing WBC within the reference range (AGUIRRE et al., 2006) or greater than this range (BEAUFILS et al., 2002; ULUTAS et al., 2007). The basophil count above the reference values for the leukocyte differential was the only significant difference $(p=0.015)$ associated with nPCR positive dogs. Although no previous study has reported basophilia in association with $A$. platys infection, basophils are known to chemotactically respond to bacterial products (RIZZI et al., 2010).

This was the first molecular study to survey the presence of the vector-borne pathogens $E$. canis and A. platys in domestic dogs in Porto Alegre, Southern Brazil. The present results indicate that CICT caused by $A$. platys may be endemic in this area. Although A. platys is considered to be less pathogenic than other species of the Anaplasmataceae family, such as $E$. canis, the impact of $A$. platys infection on animal health should not be underestimated, since infection may increase the risk of other diseases (CARDOZO et al., 2009; GAUNT et al., 2010). Our findings should be further investigated in order to fully establish the impact of canine cyclic thrombocytopenia in dogs and their potential reservoir role and co-infections with $A$. platys in Southern Brazil.

\section{Conclusions}

In this study, we reported on occurrences and molecular detection of $A$. platys in naturally infected dogs in Southern Brazil for the first time. Our results showed that for an accurate diagnosis, serological and molecular methods should be combined, since there was no correlation between PCR and serological findings, and no hematological abnormalities were associated with $A$. platys infection.

Although dogs are commonly infected with E. canis in Brazil, all the dogs from the Zoonosis Control Center and from Arquipelago of Porto Alegre, Southern Brazil, tested in this study were negative for $E$. canis infection. Thus, the prevalence of $E$. canis in these areas is either low or absent. The ELISA test for these organisms has not previously been validated for strains of Anaplasma and Ehrlichia in Brazil, and despite its widespread use in routine clinical analyses in Brazil, it may be flawed with regard to identifying native species.

\section{Acknowledgements}

This work was supported by the National Scientific and Technological Development Council (Conselho Nacional de Desenvolvimento Científico e Tecnológico, CNPq). The authors thank Dr. Ahmed Mohamed for performing the statistical analyses and IDEXX Laboratories for providing the SNAP 4Dx ${ }^{\oplus}$ tests.

\section{References}

Aguiar DM, Cavalcante GT, Pinter A, Gennari SM, Camargo LMA, Labruna MB. Prevalence of Ehrlichia canis (Rickettsiales: Anaplasmataceae) in dogs and Rhipicephalus sanguineus (Acari: Ixodidae) ticks from Brazil. J Med Entomol 2007; 44(1): 126-132. http://dx.doi. org/10.1603/0022-2585(2007)44[126:POECRA]2.0.CO;2

Aguirre E, Tesouro MA, Ruiz L, Amusategui I, Sainz A. Genetic Characterization of Anaplasma (Ehrlichia) platys in Dogs in Spain. $J$ Vet Med B Infect Dis Vet Public Health 2006; 53(4): 197-200. PMid:16629989. http://dx.doi.org/10.1111/j.1439-0450.2006.00937.x

Altschul SF, Gish W, Miller WE, Myers W, Lipman DJ. Basic local alignment search tool. J Mol Biol 1990; 215(3): 403-410. PMid:2231712.

André MR, Adania CH, Machado RZ, Allegretti SM, Felippe PAN, Silva KF, et al. Molecular and Serologic Detection of Ehrlichia spp. in Endangered Brazilian Wild Captive Felids. JWildl Dis 2010; 46(3): $1017-$ 1023. PMid:20688716.

André MR, Dumler JS, Scorpio DG, Teixeira RH, Allegretti SM, Machado RZ. Molecular detection of tick-borne bacterial agents in Brazilian and exotic captive carnivores. Ticks Tick Borne Dis 2012; 3(4): 247-253. http://dx.doi.org/10.1016/j.ttbdis.2012.04.002

Beall MJ, Chandrashekar R, Eberts MD, Cyr KE, Diniz PPVP, Mainville C, et al. Serological and Molecular Prevalence of Borrelia burgdorferi, Anaplasma phagocytophilum and Ehrlichia Species in Dogs from Minnesota. Vector Borne Zoonotic Dis 2008; 8(4): 455-464. http:// dx.doi.org/10.1089/vbz.2007.0236

Beaufils JP, Inokuma H, Martin-Granel J, Jumelle P, Barbault-Jumelle M, Brouqui P. Anaplasma platys (Ehrlichia platys) infection in a dog in France: description of the case and characterization of the agent. Rev Med Vet 2002; 153(2): 85-90.

Cardozo GP, Oliveira LP, Zissou VG, Donini IAN, Roberto PG, Marins M. Analysis of the 16S rRNA gene of Anaplasma platys detected in dogs from Brazil. Braz J Microbiol 2007; 38(3): 478-479. http://dx.doi. org/10.1590/S1517-83822007000300017

Cardozo GP, Oliveira LP, Mansur MAB, Santos EV, Roberto PG, Marins M. Molecular characterisation of two strains of Anaplasma platys in Brazil. Vet Rec 2009; 164(11): 338-339. PMid:19287032. http://dx.doi. org/10.1136/vr.164.11.338

Chandrashekar R, Mainville CA, Beall MJ, O'Connor T, Eberts MD, Alleman RA, et al. Performance of a commercially available in-clinic ELISA for the detection of antibodies against Anaplasma phagocytophilum, Ehrlichia canis, and Borrelia burgdorferi and Dirofilaria immitis antigen in dogs. Am J Vet Res 2010; 71(12): 1443-1450. PMid:21117995. http:// dx.doi.org/10.2460/ajvr.71.12.1443

Costa Jr LM, Rembeck K, Ribeiro MFB, Beelitz P, Pfister K, Passos LMF. Sero-prevalence and risk indicators for canine ehrlichiosis in three rural areas of Brazil. Vet J 2007a; 174(3): 673-676. PMid:17204439. http:// dx.doi.org/10.1016/j.tvjl.2006.11.002

Costa Jr LM. Aspectos epidemiológicos de hemoparasitoses caninas no Estado de Minas Gerais: utilização de métodos de diagnóstico direto, indireto e molecular [Dissertação]. Belo Horizonte: Universidade Federal de Minas Gerais; 2007b.

Dagnone AS, Morais HSA, Vidotto MC, Jojima FS, Vidotto O. Ehrlichiosis in anemic, thrombocytopenic, or tick-infested dogs from a Hospital population in South Brazil. Vet Parasitol 2003; 117(4): 285 290. PMid:14637030. http://dx.doi.org/10.1016/j.vetpar.2003.10.001 
Dagnone AS, Souza AI, André MR, Machado RZ. Molecular diagnosis of Anaplasmataceae organisms in dogs with clinical and microscopical signs of ehrlichiosis. Rev Bras Parasitol Vet 2009; 18(4): 20-25. PMid:20040204. http://dx.doi.org/10.4322/rbpv.01804004

Dantas-Torres F. Canine vector-borne diseases in Brazil. Parasit Vectors 2008; 1: 25. http://dx.doi.org/10.1186/1756-3305-1-25

Diniz PPVP, Schwartz DS, De Morais HSA, Breitschwerdt EB. Surveillance for zoonotic vector-borne infections using sick dogs from southeastern Brazil. Vector Borne Zoonotic Dis 2007; 7(4): 689-698. PMid:18021025. http://dx.doi.org/10.1089/vbz.2007.0129

Dumler JS, Barbet AF, Bekker CP, Dasch GA, Palmer GH, Ray $\mathrm{SC}$, et al. Reorganization of genera in the families Rickettsiaceae and Anaplasmataceae in the order Rickettsiales: unification of some species of Ehrlichia with Anaplasma, Cowdria with Ehrlichia and Ehrlichia with Neorickettsia, descriptions of six new species combinations and designation of Ehrlichia equi and 'HGE agent' as subjective synonyms of Ehrlichia phagocytophila. Int J Syst Evol Microbiol 2001; 51(Pt 6): 21452165. PMid:11760958. http://dx.doi.org/10.1099/00207713-51-6-2145

Dyachenko V, Pantchev N, Balzer HJ, Meyersen A, Straubinger RK. First case of Anaplasma platys infection in a dog from Croatia. Parasit Vectors 2012; 5: 49. http://dx.doi.org/10.1186/1756-3305-5-49

Ferreira RF, Cerqueira AMF, Pereira AM, Guimarães CM, Sá AG, Abreu FS, et al. Anaplasma platys Diagnosis in Dogs: Comparison Between Morphological and Molecular Tests. Intern J Appl Res Vet Med 2007; 5(3): 113-119.

Ferreira RF, Cerqueira AMF, Pereira AM, Velho PB, Azevedo RRM, Rodrigues ILF, et al. Cross-reaction evaluation of PCR-Anaplasma platys positive dogs tested to Anaplasma phagocytophilum antibodies by commercial ELISA. Rev Bras Parasitol Vet 2008a; 17(S1): 5-8. PMid:20059806.

Ferreira RF, Cerqueira AMF, Pereira AM, Ferreira MS, Almosny NRP. Hematologic Parameters in Polymerase Chain Reaction-Positive and -Negative Dogs for Anaplasma platys Presenting Platelet Inclusion Bodies. Intern J Appl Res Vet Med 2008b; 6(3): 185-190.

Gaunt SD, Beall MJ, Stillman BA, Lorentzen L, Diniz PPVP, Chandrashekar R, Breitschwerdt EB. Experimental infection and co-infection of dogs with Anaplasma platys and Ehrlichia canis: hematologic, serologic and molecular findings. Parasites \& Vectors 2010; 3:33. PMid:20377870 PMCid:PMC2859368. http:// dx.doi.org/10.1186/1756-3305-3-33

Götsch S, Leschnik M, Duscher G, Burgstaller JP, Wille-Piazzai W, Joachim A. Ticks and haemoparasites of dogs from Praia, Cape Verde. Vet Parasitol 2009; 166(1-2): 171-174. PMid:19729247. http://dx.doi. org/10.1016/j.vetpar.2009.08.009

Harvey JW. Thrombocytitropic Anaplasmosis (A. platys [E. platys] Infection). In: Greene CE. Infectious Diseases of the Dog and Cat. 3rd ed. St. Louis: Elsevier; 2006. p. 229-231.

Inokuma H, Raoult D, Brouqui P. Detection of Ehrlichia platys DNA in brown dog ticks (Rhipicephalus sanguineus) in Okinawa Island, Japan. J Clin Microbiol 2000; 38(11): 4219-4221. PMid:11060094 PMCid:PMC87567.

Inokuma $\mathrm{H}$, Ohno K, Onishi T, Raoult D, Brouqui P. Detection of Ehrlichial Infection by PCR in dogs from Yamaguchi and Okinawa Prefectures, Japan. J Vet Med Sci 2001; 63(7): 815-817. PMid:11503912. http://dx.doi.org/10.1292/jvms.63.815
Labarthe N, Pereira MC, Barbarini O, McKee W, Coimbra CA, Hoskins J. Serologic Prevalence of Dirofilaria immitis, Ehrlichia canis, and Borrelia burgdorferi Infections in Brazil. Vet Ther 2003; 4(1): 67-75. PMid:12756637.

Machado RZ, Andre MR, Werther K, Sousa E, Gavioli FA, Junior JFRA. Migratory and Carnivorous Birds in Brazil: Reservoirs for Anaplasma and Ehrlichia Species? Vector Borne Zoonotic Diseases 2012; 12(8): 705-708. http://dx.doi.org/10.1089/vbz.2011.0803

Mylonakis ME, Koutinas AF, Billinis C, Leontides LS, Kontos V, Papadopoulos O, et al. Evaluation of cytology in the diagnosis of acute canine monocytic ehrlichiosis (Ehrlichia canis): a comparison between five methods. Vet Microbiol 2003; 91(2-3):197-204. http://dx.doi. org/10.1016/S0378-1135(02)00298-5

M'ghirbi Y, Ghorbel A, Amouri M, Nebaoui A, Haddad, Bouattour A. Clinical, serological, and molecular evidence of ehrlichiosis and anaplasmosis in dogs in Tunisia. Parasitol Res 2009; 104(4): 767-774. http://dx.doi.org/10.1007/s00436-008-1253-4

Moraes-Filho J, Marcili A, Nieri-Bastos FA, Richtzenhain LJ, Labruna MB. Genetic analysis of ticks belonging to the Rhipicephalus sanguineus group in Latin America. Acta Trop 2011; 117(1): 51-55. PMid:20858451. http://dx.doi.org/10.1016/j.actatropica.2010.09.006

Neer MT, Harrus S. Canine monocytotropic ehrlichiosis and neorickettsiosis (E. canis, E. chaffeensis, E. ruminantium, N. sennetsu, and $N$. risticii infections). In: Greene CE. Infectious Diseases of the Dog and Cat. 3rd ed. St. Louis: Elsevier; 2006. p. 203-216.

Oliveira D, Tie Nishimori C, Costa MT, Machado RZ, Castro MB. Anti- Ehrlichia canis antibodies detection by "Dot-ELISA" in naturally infected dogs. Rev Bras Parasitol Vet 2000; 9(1): 1-5.

Perez M, Rikihisa Y, Wen B. Ehrlichia canis-like agent isolated from a man in Venezuela: antigenic and genetic characterization. J Clin Microbiol 1996; 34(9): 2133-2139. PMid:8862572 PMCid:PMC229204.

Perez M, Bodor M, Zhang C, Xiong Q, Rikihisa Y. Human infection with Ehrlichia canis accompanied by clinical signs in Venezuela. Ann N Y Acad Sci 2006; 1078: 110-117. PMid:17114689. http://dx.doi. org/10.1196/annals.1374.016

Pinyoowong D, Jittapalapong S, Suksawat F, Stich RW, Thamchaipenet A. Molecular characterization of Thai Ehrlichia canis and Anaplasma platys strains detected in dogs. Infect Genet Evol 2008; 8(4): 433-438. PMid:17643354. http://dx.doi.org/10.1016/j.meegid.2007.06.002

Ramos CAN, Ramos RAN, Araújo FR, Guedes DS Jr, Souza IIF, Ono TM, et al. Comparison of nested-PCR with blood smear examination in detection of Ehrlichia canis and Anaplasma platys in dogs. Rev Bras Parasitol Vet 2009; 18(S1): 58-62. PMid:20040193. http://dx.doi. org/10.4322/rbpv.018e1011

Ribeiro VLS, Weber MA, Fetzer LO, Vargas CRB. Espécies e prevalência das infestaçóes por carrapatos em cães de rua da cidade de Porto Alegre, RS, Brasil. Cienc Rural 1997; 27(2): 285-289. http://dx.doi.org/10.1590/ S0103-84781997000200019

Rizzi TE, Meinkoth JH, Clinkenbeard KD. Normal Hematology of the Dog. In: Weiss DJ, Wardrop KJ. Schalm's Veterinary Hematology. 6th ed. Blackwell Publishing; 2010. chap. 104, p. 799-810.

Sacchi AB, Duarte JM, André MR, Machado RZ. Prevalence and molecular characterization of Anaplasmataceae agents in free-ranging Brazilian marsh deer (Blastocerus dichotomus). Comp Immunol Microbiol Infect Dis 2012; 35(4): 325-334. http://dx.doi.org/10.1016/j. ttbdis.2012.04.002 
Saito TB, Cunha-Filho NA, Pacheco RC, Ferreira F, Pappen FG, Farias NAR, et al. Canine Infection by Rickettsiae and Ehrlichiae in Southern Brazil. Am J Trop Med Hyg 2008; 79(1): 102-108. PMid:18606772.

Santos F, Coppede JS, Pereira ALA, Oliveira LP, Roberto PG, Benedetti RBR, et al. Molecular evaluation of the incidence of Ehrlichia canis, Anaplasma platys and Babesia spp. in dogs from Ribeirāo Preto, Brazil. Vet J2009a; 179(1): 145-148. PMid:17920967. http://dx.doi.org/10.1016/j. tvjl.2007.08.017

Santos AP, Messick JB, Biondo AW, Oliveira ST, Pedralli V, Lasta CS, et al. Design, optimization, and application of a conventional PCR assay with an internal control for detection of 'Candidatus Mycoplasma turicensis' 16S rDNA in domestic cats from Brazil. Vet Clin Pathol 2009b; 38(4): 443-452. http://dx.doi.org/10.1111/j.1939165X.2009.00158.x

Santos HA, Pires MS, Vilela JA, Santos TM, Faccini JL, Baldani $\mathrm{CD}$, et al. Detection of Anaplasma phagocytophilum in Brazilian dogs by real-time polymerase chain reaction. Journal of Veterinary Diagnostic Investigation 2011; 23(4): 770-774. PMid:21908321. http://dx.doi. org/10.1177/1040638711406974
Silva JN, Almeida ABPF, Sorte ECB, Freitas AG, Santos LGF, Aguia DM, et al. Soroprevalência de anticorpos anti-Ehrlichia canis em cães de Cuiabá, Mato Grosso. Rev Bras Parasitol Vet 2010; 19(2): 108-111. PMid:20624348. http://dx.doi.org/10.4322/rbpv.01902008

Souza BMP, Leal DC, Barboza DCPM, Uzêda RS, Alcântara AC, Ferreira F, et al. Prevalence of ehrlichial infection among dogs and ticks in Northeastern Brazil. Rev Bras Parasitol Vet 2010; 19(2): 89-93. PMid:20624344. http://dx.doi.org/10.4322/rbpv.01902004

Szabó MP, Mangold AJ, João CF, Bechara GH, Guglielmone AA. Biological and DNA evidence of two dissimilar populations of the Rhipicephalus sanguineus tick group (Acari: Ixodidae) in South America. Vet Parasitol 2005; 130(1-2): 131-140. PMid:15893080. http://dx.doi. org/10.1016/j.vetpar.2005.03.008

Ulutas B, Bayramli G, Karagenç T. First Case of Anaplasma (Ehrlichia) platys Infection in a Dog in Turkey. Turk J Vet Anim Sci 2007; 31(4): 279282.

Vieira RFC, Biondo AW, Guimarães AMS, Santos AP, Santos RP, Dutra LH, et al. Ehrlichiosis in Brazil. Rev Bras Parasito Vet 2011; 20(1): 1-12. PMid:21439224. http://dx.doi.org/10.1590/ S1984-29612011000100002 